\title{
FIRST RECORD OF TOMOSTELE MUSAECOLA (MORELET, 1860) (GASTROPODA: EUPULMONATA: STREPTAXIDAE) FROM THE DOMINICAN REPUBLIC AND ITS CURRENT DISTRIBUTION IN THE WESTERN HEMISPHERE
}

\author{
Oniel AlVareZ-ABreU*, SARA Mateo, Altagracia EsPinOsa-Jorge
}

\author{
Facultad de Ciencias, Universidad Autónoma de Santo Domingo, Instituto de Investigaciones Botánicas \\ y Zoológicas Prof. Rafael M. Moscoso, Dominican Republic (e-mails: onielalvarezabreu@gmail.com; \\ s.mateo.ozorio@gmail.com; altagraciaespinosa@yahoo.com); \\ ㄴ) OAA https://orcid.org/0000-0003-4246-9475, ㄴ SM https://orcid.org/0000-0002-3610-7702, \\ (1) AR https://orcid.org/0000-0003-2504-0028 \\ *corresponding author
}

\begin{abstract}
The presence of alien mollusc species in an ecosystem has a negative impact on the endemic mollusc fauna and can result in economic losses. The West African land snail Tomostele musaecola (Morelet) was previously recorded from numerous localities in the Western Hemisphere. In this paper, we provide a new locality of this malacophagous snail in the Dominican Republic. The species is recorded from an urban park named Parque Ecológico Las Caobas in the province of San Cristóbal. In order to update the current distribution of T. musaecola in the Americas we examined the literature and the online database of the Invertebrate Zoology Collection of the Florida Museum of Natural History (FLMNH); when available, citizen science data were also used. A map is provided to illustrate the current distribution of the species in the Americas. The total number of records in the Western Hemisphere is 51, and 26 of them are part of this review. More studies are needed on the interaction of this species with the native land snails. Trade and planting of ornamental species in urban parks facilitate the establishment and expansion of alien molluscs.

KEY WORDS: alien species; hunter snail; range expansion; urban park; urban malacofauna
\end{abstract}

\section{INTRODUCTION}

Many species have been established in and introduced into new habitats due to inadvertent actions or deliberate human activities that frequently lead to ecological and economic damage (VITOUSEK et al. 1997). These non-native species affect the dynamics of biological communities, ecological processes, economy and human health; they may cause displacement or extinction of native species, resource competition, and spread of pathogens, especially on islands (CHARLES \& DUKES 2008). Molluscs are no exception among the introduced taxa. Among land snails, carnivorous species of the family Streptaxidae have been introduced throughout the tropics and subtropics. This has several implications for some native mollusc faunas (VAN BRUGGEN 1975, STANISIC 1981, NAGGS 1989).

Gulella bicolor (Hutton, 1834) and Tomostele musaecola (Morelet, 1860) are distinctive introduced streptaxids, also known as "hunter snails". They have been introduced circumtropically into the Caribbean Basin, south-eastern United States of America, northern part of South America, São Tomé and Príncipe, Australia, Melanesia, Micronesia and Polynesia (AufFenberg \& StANGe 2001, Cowie 2001, HAUSDORF \& MEDINA BERMÚdEZ 2003, ROBINSON et al. 2009, BRODIE \& BARKER 2012a, 
Gerber \& Clark 2015, Miquel \& Herrera 2019, HOLYOAK et al. 2020). G. bicolor is a known predator of small invertebrates; it has been reported to feed on subulinid and pupillid snails and earthworms (MEAD 1961, DundeE \& BAERWALD 1984, AUfFENBERG \& STANGE 2001, BRODIE \& BARKER 2012a).

T. musaecola is a small, non-operculated snail whose shell, with 8.75 whorls in total, is elongated (height up to $6.7 \mathrm{~mm}$ ), imperforated, crystalline to whitish, with a narrow apex and similar diameter of mid-spire and body whorl. The protoconch is smooth while the teleoconch surface is covered with prominent radial ribs. The aperture is almost trapezoidal and its palatal lip is thickened and arched forward without apertural barriers. Its fairly concave columella has an oblique truncation at the base, the parietal callus is thick (PILSBRY 1930, SOLEM 1989, MiQUEL \& HERRERA 2019). The body colour is translucent white with hints of pale green.

This carnivorous snail originally comes from West Africa. The species was first recorded in the Western Hemisphere at Port of Spain in Trinidad as Luntia insignis E. A. Smith, 1898 which was much later synonymised with Streptostele (Tomostele) musaecola (Morelet, 1860) by HAUSDORF \& MEDINA BERMÚDEZ (2003). Recently HOLYOAK et al. (2020) raised the

\section{MATERIAL AND METHODS}

\section{STUDY AREA}

The study was carried out at Parque Ecológico Las Caobas, located in the province of San Cristóbal, Dominican Republic $\left(18^{\circ} 25.00^{\prime} \mathrm{N}, 70^{\circ} 07.20^{\prime} \mathrm{W} ; 88 \mathrm{~m}\right.$ a.s.l.). This natural monument, $160,524 \mathrm{~m}^{2}$ in area, is an urban park with many planted stands of Swietenia mahagoni (mahogany) and other native and exotic plant species (Figs 1, 2).

We selected an area with a mixture of trees, herbs and vines. The main tree species were Albizia saman, Citrus sp., S. mahagoni, Mangifera indica, Melicoccus bijugatus and Guazuma ulmifolia. A. saman and S. mahagoni were the major leaf litter contributors. Prominent patches of the exotic-invasive vine species Antipogon leptopus (coral vine) and Centrosema sp. covered the ground. Besides, herbs such as Priva lappulacea, Spermacoce remota and Chamaesyce hirta and a few fern species were present.

\section{SAMPLING}

Samples were taken during three field trips in February and April 2019 and October 2020, between 9:00 and 15:00. We selected one fixed transect, 100 $\mathrm{m}$ long and $2 \mathrm{~m}$ wide, where the average temperature and humidity were measured with a weather subgenus to the generic rank, based on the comparison of the columella truncation and shell size of Príncipe Island taxa and T. musaecola.

In the following years, as a result of human activities, it was inadvertently introduced to other countries of the Western Hemisphere and was recorded from 25 localities in Central and South America, and in the Caribbean (HAUSDORF \& MEDINA BERMÚdEZ 2003, Robinson et al. 2009, GERBER \& ClARK 2015). It is known that T. musaecola is malacophagous, and it is supposed that its introduction to islands such as American Samoa has had a profound impact on native snails, leading to the extinction of indigenous species (COWIE 1998, HAUSDORF \& MEDINA BERMÚDEZ 2003). The threat T. musaecola poses to native molluscs is still undocumented in other territories where it has been introduced (ROBINSON et al. 2009, BRODIE \& BARKER 2012b, DELANNOYE et al. 2015, GERBER \& CLARK 2015).

Here, we present data on a new record of T. musaecola in the Dominican Republic and update the information on the distribution presented by HAUSDORF \& MEDINA BERMÚdEZ (2003), ROBINSON et al. (2009) and GERBER \& CLARK (2015) for the Western Hemisphere, extending the distribution range.

meter (Kestrel 4500). Following SUÁREZ-TORRES \& FERNÁNDEZ-VELÁZQUEZ's (2012) categories, an intensive search through all possible microhabitats was performed on each field trip in order to collect as many species and individuals as possible. An opportunistic collecting was also carried out outside the transect.

Large specimens of terrestrial gastropods were collected by eye. To collect minute shells and juveniles, leaf litter from different points within the transect was taken to the laboratory of the Instituto de Investigaciones Botánicas y Zoológicas Rafael M. Moscoso (IIBZ) where it was passed through sieves of different mesh sizes. All collected material was cleaned, labelled and deposited in the malacological collection of the IIBZ. Live specimens were relaxed by drowning them overnight in small containers with water and menthol crystals, and then preserved in a $70 \%$ ethanol solution. Measuring eyepiece was used for shell measurements of T. musaecola; we followed PILSBRY's (1930) criteria to distinguish adults from juveniles.

Species identification was based on the literature (TRYON \& Pilsbry 1889, WAgner 1907, VANATTA 1920, PILSBRY 1933, CLENCH 1962, SCHILEYKO 2006) and comparative specimens from the IIBZ malacological collection. The nomenclature of the species follows ESPINOSA \& ROBINSON (2021). 
The literature and the online database of the Invertebrate Zoology Collection of the Florida Museum of Natural History (FLMNH) were revised in order to add any records missing in the earlier reviews. Citizen science data (see Results) were used as proposed by VENDETTI et al. (2018) for updating the information on the distribution of T. musaecola in the Americas. Coordinates were assigned to those records which had lacked them in the previous sources, following the instructions given by WIECZOREK et al. (2004) and MURPHY (2020). To prepare the maps, we used the open source program QGIS version 3.16.1.

\section{1}
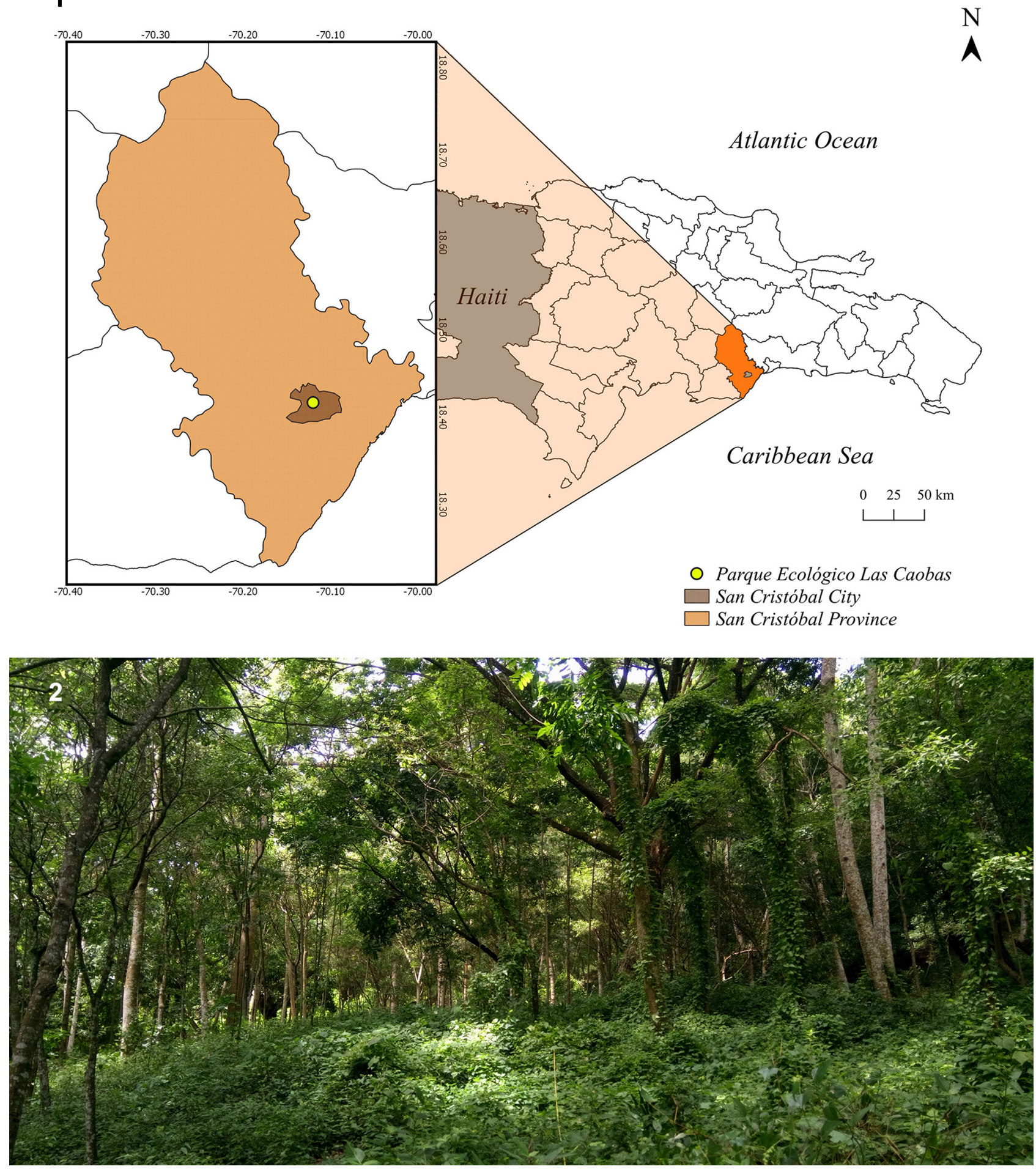

Figs 1-2. Study area: 1 - location of the study area; 2 - wooded area of Parque Ecológico Las Caobas (area with high density of the exotic coral vine) 


\section{RESULTS}

A total of 51 specimens of T. musaecola were collected. Only five of them (three adults and two juveniles) were found alive (Figs 3-8) beneath the litter, vines and herb mat, at the average temperature of $28.4{ }^{\circ} \mathrm{C}$ and humidity of $63.4 \%$. The shell height of 46 of these specimens ( 26 adult and 20 juvenile) was measured. It ranged from 1.10 to $6.00 \mathrm{~mm}$, with the mean of $4.10 \mathrm{~mm}$. Adult shell height varied from 4.50 to $6.00 \mathrm{~mm}$, with the mean of $5.39 \mathrm{~mm}$, while juvenile shells ranged from 1.10 to $4.30 \mathrm{~mm}$ (mean $2.50 \mathrm{~mm}$ ).

We recorded 609 individuals of 10 gastropod taxa and seven families which co-occurred with T. musaecola (Table 1). Two species could be identified only to the genus level due to their significantly damaged shells.

We documented 26 locality records for T. musaecola in the Western Hemisphere (18 from literature, four based on observations, two via personal communication, one occurrence in an online collection database, and the new locality recorded herein). Of these 26 locality records mentioned, 24 are insular and two continental (Fig. 9); they are added to the 25 reviewed by HAUSDORF \& MEDINA BERMÚdEZ (2003), ROBINSON et al. (2009) and GERBER \& CLARK (2015), which makes 51 occurrences in the Western Hemisphere known to date:

- Lesser Antilles. GUADELOUPE: Basse-Terre Island $\quad\left(16^{\circ} 08.96^{\prime} \mathrm{N}, \quad 61^{\circ} 40.71^{\prime} \mathrm{W}\right)$, GrandeTerre Island $\left(16^{\circ} 19.34^{\prime} \mathrm{N}, 61^{\circ} 25.58^{\prime} \mathrm{W}\right)$ and Marie-Galante Island $\left(15^{\circ} 55.89^{\prime} \mathrm{N}, 61^{\circ} 16.14^{\prime} \mathrm{W}\right)$ (BERTRAND 2001, ChARles 2015, 2016); Not specified (ANTUNES et al. 2018). MARTINIQUE: Morne Gras, Bellefontaine Commune $\left(14^{\circ} 40.46^{\prime} \mathrm{N}\right.$, $\left.61^{\circ} 08.81^{\prime} \mathrm{W}\right), \quad$ Morne Caroline, Case-Pilote Commune $\left(14^{\circ} 38.95^{\prime} \mathrm{N}, \quad 61^{\circ} 07.41^{\prime} \mathrm{W}\right)$, Fond Moulin, Grand'Rivière Commune $\left(14^{\circ} 52.47^{\prime} \mathrm{N}\right.$, $\left.61^{\circ} 10.85^{\prime} \mathrm{W}\right)$, route forestière de Palourde, GrosMorne Commune $\left(14^{\circ} 42.16^{\prime} \mathrm{N}, \quad 61^{\circ} 02.43^{\prime} \mathrm{W}\right)$, chemin forestier de la Propreté, Le MorneRouge Commune $\left(14^{\circ} 45.54^{\prime} \mathrm{N}, \quad 61^{\circ} 06.49^{\prime} \mathrm{W}\right)$, Anse Couleuvre, Le Prêcheur Commune $\left(14^{\circ} 50.566^{\prime} \mathrm{N}, 61^{\circ} 13.13^{\prime} \mathrm{W}\right)$, Morne Baldara, Le François Commune $\left(14^{\circ} 34.66^{\prime} \mathrm{N}, \quad 60^{\circ} 54.53^{\prime} \mathrm{W}\right)$ and Fontaine Notre-Dame, Le Vauclin Commune $\left(14^{\circ} 32.72 ' \mathrm{~N}, \quad 60^{\circ} 50.34^{\prime} \mathrm{W}\right.$ ) (DELANNOYe et al. 2015); observation by Delannoye in 2005 at Fortde-France Commune $\left(14^{\circ} 41.57^{\prime} \mathrm{N}, 61^{\circ} 05.77^{\prime} \mathrm{W}\right)$ (INVENTAIRE NATIONAL DU PATRIMOINE NATUREL 2019); observations by Gargominy in 2001 at De l'Anse Couleuvre aux cascades du Mont Conil, Le Prêcheur Commune $\left(14^{\circ} 51.39^{\prime} \mathrm{N}, 61^{\circ} 12.58^{\prime} \mathrm{W}\right)$ and Gargominy, Delannoye \& Machon in 2011 at Presqu'île de la Caravelle, La Trinité Commune $\left(14^{\circ} 45.27^{\prime} \mathrm{N}, 60^{\circ} 56.30^{\prime} \mathrm{W}\right)$ (INVENTAIRE NATIONAL DU PATRIMOINE NATUREL 2020).

- Greater Antilles. CUBA: Not specified (EsPINOSA et al. 1994, ESPINOSA \& ORTEA 1999); All Cuban territory (PÉREZ et al. 1996); Instituto de Investigaciones de Pastos y Forrajes de Niña Bonita, Cangrejeras, La Habana Province $\left(23^{\circ} 02.33^{\prime} \mathrm{N}, 82^{\circ} 29.39^{\prime} \mathrm{W}\right)$ (CABRERA DÁvila et al. 2004); Not specified (ROBINSON personal communication 2007); Sierra La Guasasa, Viñales, Pinar del Río Province $\left(22^{\circ} 39.48^{\prime} \mathrm{N}, 83^{\circ} 42.43^{\prime} \mathrm{W}\right)$ (OlIVA-OlIVERA \& REAL 2009); Occidental Region (MACEIRA et al. 2013). DOMINICAN REPUBLIC: Parque Ecológico Las Caobas, San Cristóbal, San Cristóbal Province $\left(18^{\circ} 25.00^{\prime} \mathrm{N}, \quad 70^{\circ} 07.20^{\prime} \mathrm{W}\right)$. PUERTO RICO: Not specified (ROBINSON personal communication 2007, ROBINSON \& FIELDS 2014).

- South America. ECUADOR: Guayabillos, Santa Cruz Island, Galápagos Province $\left(0^{\circ} 41.78^{\prime} \mathrm{S}\right.$,

Table 1. List of species co-occurring with T. musaecola in an area of $200 \mathrm{~m}^{2}$ in Parque Ecológico Las Caobas, and the number of individuals recorded

\begin{tabular}{llcc}
\hline \multicolumn{1}{c}{ Family } & \multicolumn{1}{c}{ Species } & No. & Alien/Endemic/Native \\
\hline Achatinidae & Subulina octona (Bruguière, 1792) & 1 & Alien \\
Cepolidae & Coryda monodonta (Lea, 1831) & 5 & Endemic \\
Helicinidae & Alcadia succinea (L. Pfeiffer, 1850) & 215 & Endemic \\
& Fadyenia domingensis (Vanatta, 1920) & 164 & Endemic \\
Oleacinidae & Vagavarix sp. & 1 & - \\
Sagdidae & Hispaniolana undulata (Férussac, 1821) & 26 & Endemic \\
& Hojeda inaguensis (Weinland, 1880) & 157 & Native \\
Solaropsidae & Lacteoluna selenina (Gould, 1848) & 3 & Alien \\
Thysanophoridae & Caracolus sp. & 8 & Alien \\
& Lyroconus plagioptycha (Shuttleworth, 1854) & 29 & 609 \\
\hline
\end{tabular}


$\left.90^{\circ} 20.78^{\prime} \mathrm{W}\right)$ (MIQUEL \& HERRERA 2019). FRENCH GUIANA: observation by Ripken \& Gargominy in 1999 at Parc Amazonien de Guyane à Saül, Saül Commune $\left(3^{\circ} 37.32^{\prime} \mathrm{N}, 53^{\circ} 12.54^{\prime} \mathrm{W}\right)$ (INVENTAIRE NATIONAL DU PATRIMOINE NATUREL
2020). VENEZUELA: four specimens from the FLMNH (UF 383614) collected by Lionel \& Miller in 1986 at Gruta De Lourdes, San Sebastián, Aragua State $\left(9^{\circ} 57.36^{\prime} \mathrm{N}, 67^{\circ} 10.82^{\prime} \mathrm{W}\right)$ (PAULAY \& BROWN 2020).

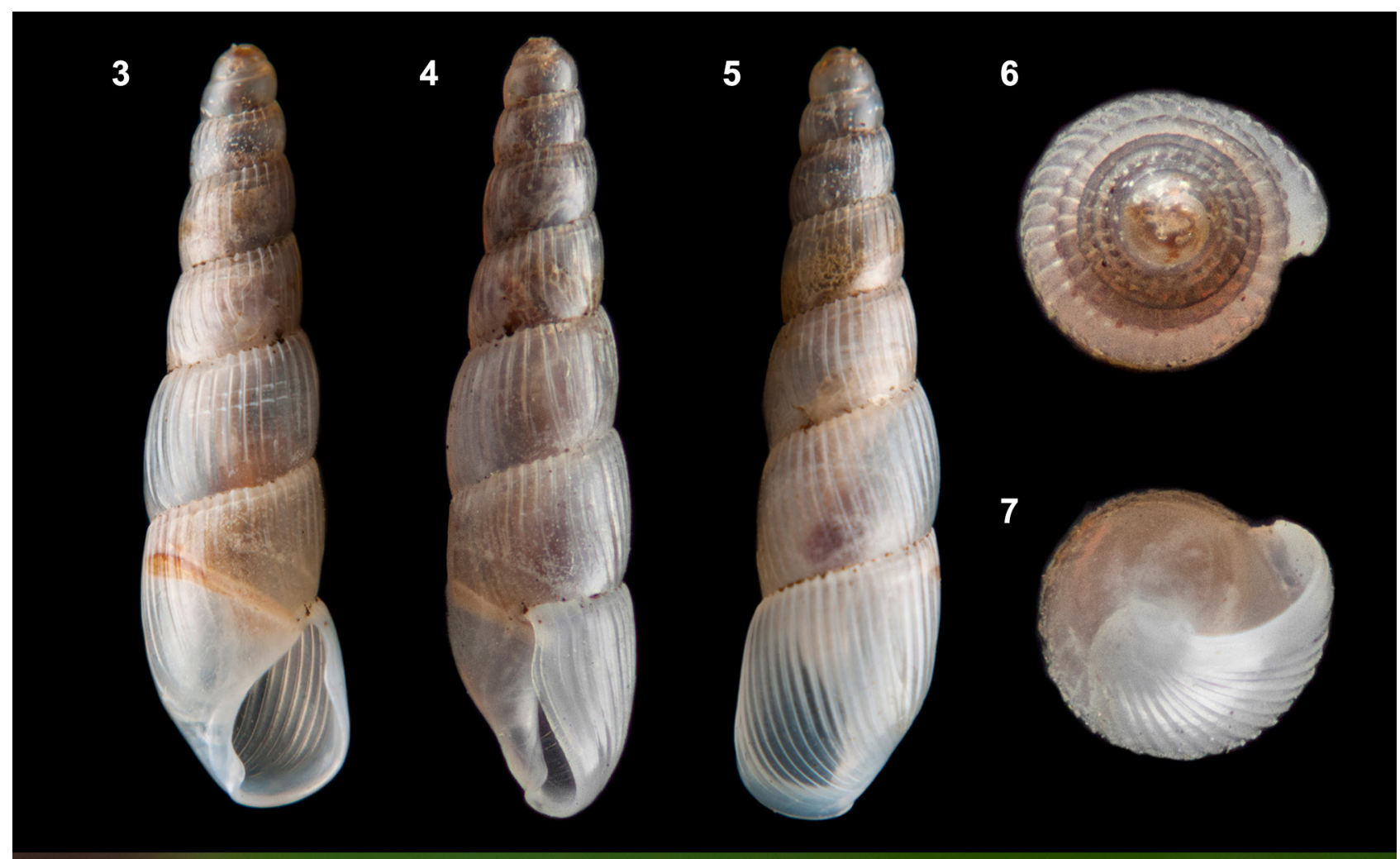

8

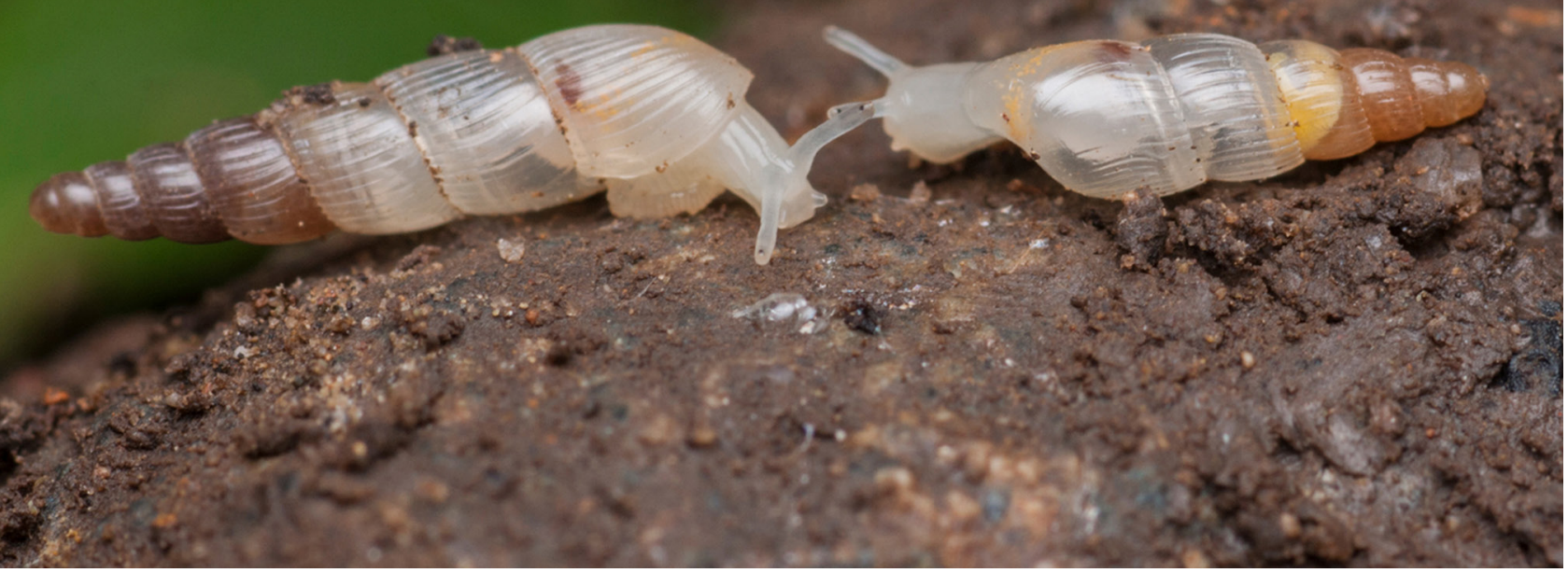

Figs 3-8. Tomostele musaecola: 3 - ventral view; 4 - lateral view; 5 - dorsal view; 6 - apex; 7 - base; 8 - live adult and juvenile individuals 


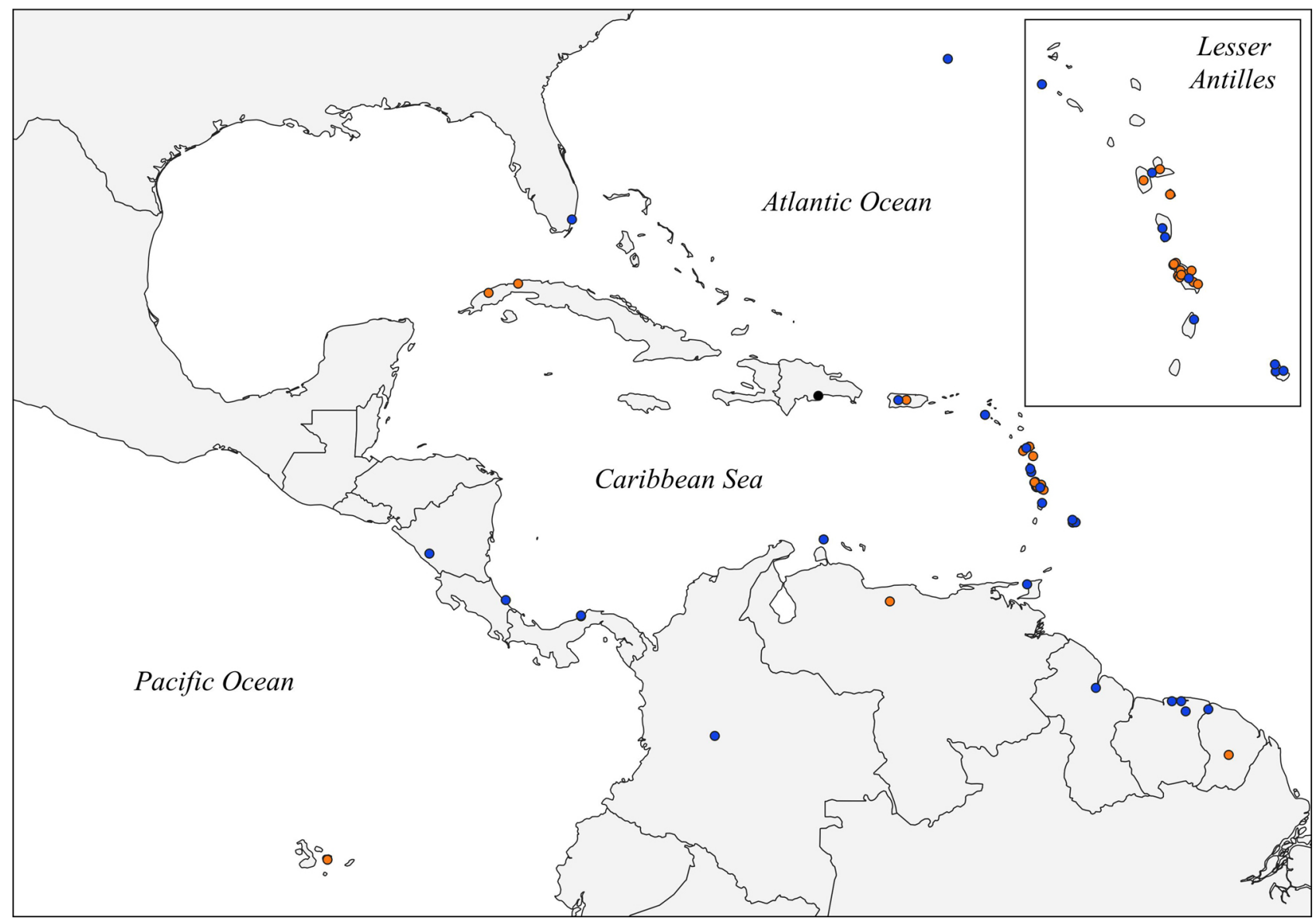

Fig. 9. Distribution of Tomostele musaecola in the Western Hemisphere. Blue and orange dots represent localities reported by previous authors and added in this article, respectively. The new Hispaniolan locality is indicated in black

\section{DISCUSSION}

Tropical habitats of originally high biodiversity, which are much modified by human intervention, seem to facilitate the range expansion and establishment of fast-adapting alien species (PRENTIS et al. 2008, SAVITRI NURINSIYAH et al. 2016). T. musaecola may be one of such highly adaptable species (FONTAINE et al. 2007).

The introduction of T. musaecola in the Western Hemisphere dates from more than a century ago (SMITH 1898). Since then new localities within the Americas have been reported. These reports have only focused on providing new records, but with no information on the effects of this species on the native mollusc populations in the Americas. Publications by Pilsbry (1930), Oliva-Olivera \& ReAl (2009) and GEBERT \& CLARK (2015) provide compilations of data on T. musaecola and associated molluscs, but ecological data are limited to a minimum.

Fifty one localities of T. musaecola were reported from the American continent prior to 2020; 26 of those are reviewed here. These 26 occurrences include 11 localities overlooked (three from Guadeloupe, six from for Cuba, one in Puerto Rico, and one in Venezuela) in the previous reviews by HAUSDORF \& MEDINA BERMÚdEZ (2003), ROBINSON et al. (2009) and GERBER \& Clark (2015), as well as 14 localities in our review (11 in Martinique, one in Guadeloupe, one in Ecuador, and one in a national park in French Guiana) which were added after 2015. The last occurrence corresponds to our new locality report (San Cristóbal, Dominican Republic).

The Cuban records of the snail date back to 1994 (ESPINOSA et al. 1994). T. musaecola was reported throughout the literature from a few Cuban localities. It was even suggested that it was distributed over the whole Cuban territory (PÉREZ et al. 1996), while other authors argued that its range on the island was restricted to the Western Region (MACEIRA et al. 2013). Our findings corroborate the data presented by MACEIRA et al. (2013), therefore the claim that $T$. musaecola is found throughout the whole Cuban territory is doubtful.

Despite the wide distribution in the Caribbean Basin, T. musaecola was not found on Jamaica and the Bahamas. Its introduction to these localities in the near future is plausible, due to the commercial and 
touristic interchanges between the Caribbean Islands. No other records have been reported, apart from the previous ones, from other Central American countries. In South America the expansion continues. Peculiar situations are those in French Guiana, where the species occurs within a national park, and in the Galapagos where it is very likely to have been introduced from the equatorial continental zone (alternatively, it may have been introduced via Galapagos to continental Ecuador).

Anthropogenic disturbance presents a threat to micro-molluscs (DougLAs et al. 2013); many species have been introduced to these disturbed areas, increasing the risk of extinction of the native mollusc fauna. Some species of terrestrial molluscs, such as Subulina octona (Bruguière, 1792), Bradybaena similaris (Férussac, 1822) and Deroceras leave (Müller, 1774) (BRODIE \& BARKER 2011, MACEIRA et al. 2013) are thought to be associated with anthropogenic transformations. OLIVA-OLIVERA \& REAL (2009) regard T. musaecola as a potential indicator of anthropogenic and circum-anthropogenic changes. In Cuba, it has been reported to occur in secondary forests and lawns (ESPINOSA \& ORTEA 1999, MACEIRA et al. 2013), and it has been found in disturbed areas in Puerto Rico and associated islands (ROBINSON \& FIELDS 2014). On Fiji and other Pacific islands, this species has been recorded in disturbed lowland forests (BARKER et al. 2005, BRODIE \& BARKER 2012a, b). Our new record of T. musaecola also comes from an anthropogenically transformed suburban area.

The introduction and invasion of ornamental plants in the natural vegetation cover bordering suburban environments, as well as deliberate planting, often lead to introduction and range expansion of alien molluscs in these areas. It is noteworthy that many species have been introduced as a result of commercial activities such as agriculture and horticulture (MEYERSON \& MOONEY 2007). T. musaecola has been found associated with plantations of Cocos nucifera (coconut) (ROBINSON personal communication 2007) and Theobroma cacao (cocoa) (OKE \& OMOREGIE 2012), and supposedly introduced via importations of banana (Musa $\times$ paradisiaca) (PILSBRY 1930). GEBERT \& CLARK (2015) also suggest that the introduction of T. musaecola to Florida may have been due to trade in horticultural products. It is also worth mentioning that our study area is mainly covered by mahogany plantations and stands of other planted trees.

MORELET (1860) described T. musaecola from Guinea, apparently inhabiting the trunks of Musaceae. Nevertheless, the syntypes from the Natural History Museum (NHMUK 1893.2.4.276-278), collected by Morelet himself and figured by BREURE et al. (2018), originate from Gabon (Figs 10-11). GERBER \& CLARK (2015) proposed, tentatively, an extension of the native range of the species from Guinea to the Congo; however, T. musaecola might not be native to all areas in western-central Africa. According to OKE \& OMOREGIE (2012), the species was recorded in Nigerian cocoa plantations, but they provide no information on whether T. musaecola was native or alien in this west African country. HOLYOAK et al. (2020) recorded the species from the islands of São Tomé and Príncipe, included it in introduced species of these islands, and restricted the type locality of the species to Gabon, based on BREURE et al. (2018). The native range of the species seems to be uncertain.

Urban parks in the Dominican Republic have variable levels of protection, where many of them are isolated and used for recreation. These parks contribute to the studies of biodiversity monitoring and survival of indigenous species, and are habitats for native and alien species. In many cases, the introduction of species is due to incorporation of materials, furniture and plants used for the aesthetical pleasing and adequacy of these green areas; it constitutes a direct or indirect danger to autochthonous species. Hypothetically, we propose that T. musaecola, along with the other introduced land snails species, was established in the study area by these scenarios.

Hispaniola is one of the least malacologically explored islands in the Caribbean Basin. This situation has led to a lack of knowledge regarding an approx-

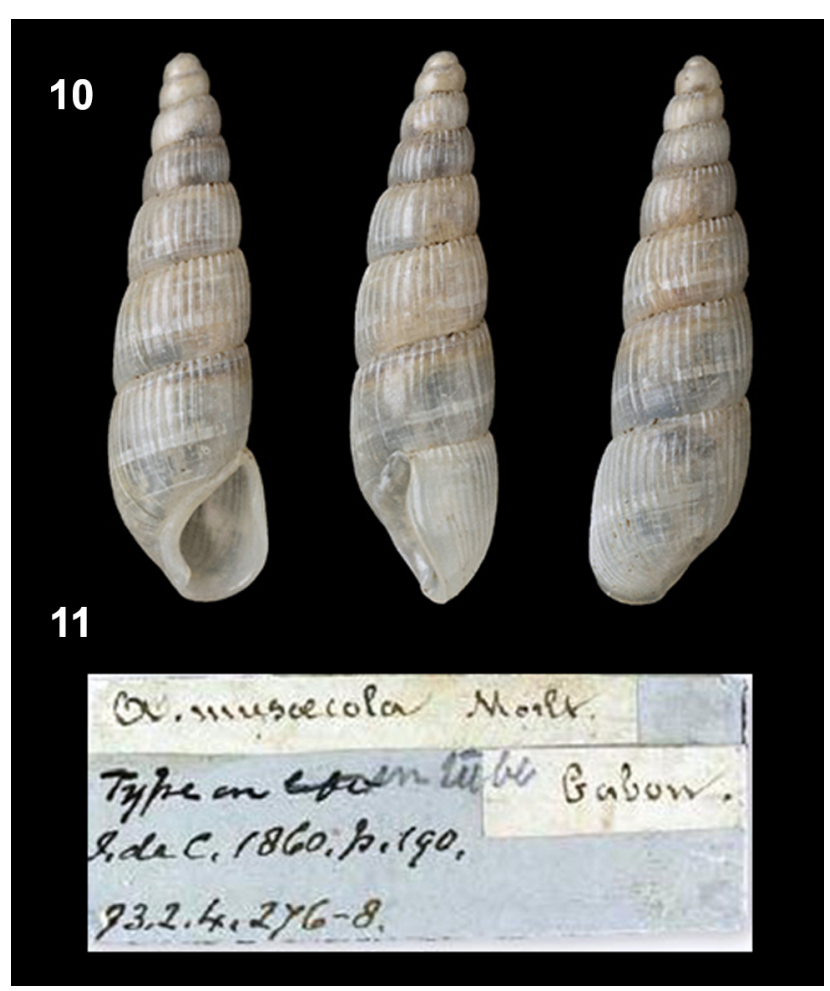

Figs 10-11. Achatina musaecola Morelet, 1860: 10 - syntype NHMUK 1893.2.4.276, $5.9 \mathrm{~mm}$; 11 - label of $A$. musaecola (NHMUK 1893.2.4.276-278). Modified from BREURE et al. (2018) 
imation of faunistic richness and the ecological role of molluscs in its habitats. Minute land snails are the main undiscovered group from the Hispaniolan malacofauna, and the introduction of malacophagous land snails such as T. musaecola represents a risk to these poorly explored autochthonous species.

Among 660 specimens collected in the study area, T. musaecola represent $8 \%$ of the total number. The presence of T. musaecola could act as a pressure over the remaining carnivorous species in the study area (Vagavarix sp.), because of its higher density in comparison to that of the oleacinid. Due to the low numbers of specimens of Subulina octona and Lacteoluna selenina, previously reported as being associated with $T$. musaecola (Oliva-OLIVERA \& REAL 2009, DELANNOYE et al. 2015), we could infer that T. musaecola might be feeding on individuals of Alcadia succinea, Fadyenia domingensis, Hojeda inaguensis and Lyroconus plagioptycha. This might be particularly dangerous as two of these are endemic to the island. These are simple non-empirical scenarios as no concrete observations on these situations were performed.

\section{REFERENCES}

ANTUnes N., Charles L., Bertrand A., Lenoble A. 2018. Mollusques terrestres de Guadeloupe, le point sur 20 années de recherche. Colloque national de malacologie continentale, Nantes, France.

AuffenberG K., StANGE L. A. 2001. Snail-eating snails of Florida, Gastropoda. IFAS Extension, University of Florida, EENY 251: 1-4.

BArker G. M., Price R., Briggs C. 2005. Priorities for additions to the Fijian protected natural areas network: an assessment based on complementarity in land snail assemblages. New Zealand Land care Research contract report prepared for Wildlife Conservation Society, Suva.

BERTRAND A. 2001. Notes préliminaires sur les mollusques terrestres de Guadeloupe. Rapport d'étude. Direction régionale de l'Environnement et de l'Aménagement du Territoire, Basse-Terre.

Breure A. S. H., Audibert C., Ablett J. D. 2018. Pierre Marie Arthur Morelet (1809-1892) and his contributions to malacology. Nederlandse Malacologische Vereniging, Leiden.

BRODIE G., BARKER G. M. 2011. Introduced land snails in the Fiji Islands: are there risks involved? In: VEITCH C. R., Clout M. N., Towns D. R. (eds). Island invasives: eradication and management. IUCN, Gland, Switzerland, pp. 32-36.

BRodie G., BARKER G. M. 2012a. Gulella bicolor (Hutton, 1834). Family Streptaxidae. USP Introduced Land Snails of the Fiji Islands Fact Sheet Series, No. 5.

BRODIE G., BARKER G. M. 2012b. Streptostele musaecola (Morelet, 1860). Family Streptaxidae. USP Introduced Land Snails of the Fiji Islands Fact Sheet Series, No. 6.
Although the predatory behaviour of T. musaecola is known, its role in the extinction of the native mollusc fauna in regions where it has been introduced, has not been documented. More studies are needed on the interaction of this species with native land snail species.

\section{ACKNOWLEDGEMENTS}

We thank JUDÁ MARTÍNEZ who accompanied us on the field trips and took the photographs of the specimens, as well as PAMELA REYES and ROSA LAUREANO for their support. Moreover, we are grateful to AMÉRICA SÁNCHEZ for her suggestions and DAVID MACEIRA and RUTH BASTARDO for their help during the field trips and for their valuable comments on the manuscript. We thank ABRAHAM S. H. BREure, CÉDriC AudibERT and JONATHAN D. ABLETT for sending us literature and permission to use the cited figures from their book. We are most grateful to the anonymous reviewers for their valuable suggestions which helped to improve the manuscript.

Cabrera dávila G. C., Martínez M. A., Aragonés C. R. 2004. La macrofauna del suelo como bioindicador del estado de perturbación de los ecosistemas. GEOTECH, La Habana, Cuba.

CHARles L. 2015. Mollusques terrestres de l'archipel de la Guadeloupe, Petites Antilles. Rapport d'inventaire 2014-2015. DEAL Guadeloupe.

CHARLES L. 2016. Inventaire des mollusques terrestres de Guadeloupe, Petites Antilles: données préliminaires. MalaCo 12: 47-56.

CHARLES H., DUKES J. S. 2008. Impacts of invasive species on ecosystem services. In: NENTWIG W. (ed.). Biological invasions. Ecological studies (analysis and synthesis), vol. 193. Springer, Berlin, Heidelberg, pp. 217-237. https://doi.org/10.1007/978-3-540-36920-2_13

ClenCH W. J. 1962. New land mollusks in the families Camaenidae and Fruticicolidae from Hispaniola. Revista del Museo Argentino de Ciencias Naturales "Bernardino Rivadavia" 8: 213-227.

COWIE R. H. 1998. Catalog of the nonmarine snails and slugs of the Samoan Islands. Bishop Museum Press, Honolulu.

COWIE R. H. 2001. Invertebrate invasions on Pacific Islands and the replacement of unique native faunas: a synthesis of the land and freshwater snails. Biological Invasions 3: 119-136. https://doi.org/10.1023/A:1014529019000

Delannoye R., Charles L., POINTIER J.-P., MASSEMin D. 2015. Mollusques continentaux de la Martinique. Non-marine molluscs of Martinique, Lesser Antilles. Muséum national d'Histoire naturelle, Paris. 
Douglas D. D., Brown D. R., Pederson N. 2013. Land snail diversity can reflect degrees of anthropogenic disturbance. Ecosphere 4: 1-14. https://doi.org/10.1890/ES12-00361.1

DUNDEE D. S., BAERWALD R. J. 1984. Observations on a micropredator, Gulella bicolor (Hutton) (Gastropoda: Pumonata: Streptaxidae). The Nautilus 98: 63-68.

EsPinOSA J., ORTEA J. 1999. Moluscos terrestres del archipiélago cubano. Avicennia. Revista Ecología, Oceanología y Bioversidad Tropical Suppl. 2: 1-137.

ESPINOSA J., ORTEA J., VAldÉs A. 1994. Clasificación taxonómica y endemismos de los moluscos terrestres de Cuba. Avicennia. Revista Ecología, Oceanología y Bioversidad Tropical 1: 111-124.

EspinosA J. A., Robinson D. G. 2021. Annotated checklist of the terrestrial mollusks (Mollusca: Gastropoda) from Hispaniola Island. Novitates Caribaea 17: 71-146. https://doi.org/10.33800/nc.vi17.250

Fontaine B., GARgominy O., NeUbert E. 2007. Land snail diversity of the Savanna/Forest mosaic in Lopé National Park, Gabon. Malacologia 49: 313-338. https://doi.org/10.4002/0076-2997-49.2.313

Gerber J., Clark S. A. 2015. First record of the predatory land snail Streptostele (Tomostele) musaecola (Pulmonata: Streptaxidae) in the continental United States. American Conchologist 43: 26-28.

HAusdorf B., MedinA Bermúdez C. I. 2003. Luntia insignis E. A. Smith, 1898 is a synonym of Streptostele (Tomostele) musaecola (Morelet, 1860) (Gastropoda: Streptaxidae) an African tramp and its distribution in America. Malacologia 45: 185-187.

HOLYOAK D. T., HOLYOAK G. A., DE Lima R. F., PANISI M., SINCLAIR F. 2020. A checklist of the land Mollusca (Gastropoda) of the islands of São Tomé and Príncipe, with new records and descriptions of new taxa. Iberus 38: 219-319.

INVENTAIRE NATIONAL DU PATRIMOINE NATUREL 2019. Données naturalistes de Delannoye Régis. Version 1.1. UMS Patri Nat (OFB-CNRS-MNHN), Paris. https://doi.org/10.15468/ghvm9p

INVENTAIRE NATIONAL DU PATRIMOINE NATUREL 2020. Données naturalists d'Olivier Gargominy saisies sous card Obs. Version 1.1. UMS Patri Nat (OFB-CNRSMNHN), Paris. https://doi.org/10.15468/b9iw2c

Maceira D., MiQuel S. E., Espinosa J., Virgillito M., LAURANZÓN B. 2013. Moluscos terrestres exóticos y primera cita de la familia Punctidae (Mollusca: Pulmonata: Gastropoda) y de su especie Paralaoma servilis para Cuba. Solenodon 11: 95-102.

MEAD A. R. 1961. The giant African snail: a problem in economic malacology. University of Chicago Press, Chicago.

Meyerson L. A., MoOney H. A. 2007. Invasive alien species in an era of globalization. Frontiers in Ecology and the Environment 5: 199-208.

https://doi.org/10.1890/1540-9295(2007)5[199:IASIAE]2.0.CO;2

Miquel S. E., Herrera H. W. 2019. Contribution to the knowledge of selected land gastropods of Galápagos
(Ecuador) (Mollusca, Cycloneritomorpha and Stylommatophora). Spixiana 42: 185-191.

MORELET A. 1860. Descriptions de nouvelles espèces de l'Afrique occidentale, rapportées par $\mathrm{M}$. le capitaine Vignon. Journal de Conchyliologie 8: 189-191.

MURPHY S. 2020. Locality uncertainty and georeferencing. In: SMITH A. B., MURPHY S., ERICKSON K. (Webinar of the Global Change Conservation Lab at the Missouri Botanical Garden). Using museum and herbarium specimen data in ecology, evolution, and conservation (PowerPoint presentation).

NAGGS F. 1989. Gulella bicolor (Hutton) and its implications for the taxonomy of streptaxids. Journal of Conchology 33: $165-168$.

OKE C. O., OMOREGIE C. E. 2012. Land snail species richness in a cocoa agro-forest in Ile-Oluji, Ondo State, Nigeria. The Zoologist 10: 40-47.

Oliva-Olivera W., ReAL R. 2009. Moluscos terrestres de las elevaciones cársticas de Viñales, Pinar del Río, Cuba. Revista de Biología Tropical 57: 589-604. https://doi.org/10.15517/rbt.v57i3.5477

PAULAY G., BROWN W. 2020. UF Invertebrate Zoology. Florida Museum of Natural History. https://doi.org/10.15468/sm6qo6

PÉreZ A. M., VillaseCA J. C., Zione N. 1996. Sinecología básica de moluscos terrestres en cuatro formaciones vegetales de Cuba. Revista de Biología Tropical 44: 133-146.

PILsBry H. A. 1930. Results of the Pinchot South Sea Expedition: II. Land Mollusks of the Canal Zone, the Republic of Panama, and the Cayman Islands. Proceedings of the Academy of Natural Sciences of Philadelphia 82: 339-354.

PILSBRY H. A. 1933. Santo Domingo land mollusks collected by Samuel C. Pease, 1932, and by A. A. Olsson, 1916. Proceedings of the Academy of Natural Sciences of Philadelphia 85: 121-162.

Prentis P. J., Wilson J. R. U., DORMONTT E. E., RiChARDSON D. M., LOWE A. J. 2008. Adaptive evolution in invasive species. Trends in Plant Science 13: 288-294.

https://doi.org/10.1016/j.tplants.2008.03.004

Robinson D. G., FIELDS A. 2014. Preliminary report on the terrestrial malacofauna of Puerto Rico and associated islands. Conference: Mollusca 2014. El Encuentro de las Américas. At Universidad Nacional Autónoma de México, Ciudad Universitaria, Mexico City, Mexico. https://doi.org/10.13140/2.1.3985.0561

Robinson D. G., Hovestadt A., Fields A., Breure A. S. H. 2009. The land Mollusca of Dominica (Lesser Antilles), with notes on some enigmatic or rare species. Zoologische Mededelingen 83: 615-650.

SAVITRI NURINSIYAHA A., FAUZIA H., HENNIG C., HAUSDORF B. 2016. Native and introduced land snail species as ecological indicators in different land use types in Java. Ecological Indicators 70: 557-565. https://doi.org/10.1016/j.ecolind.2016.05.013

SCHILEYKo A. A. 2006. Treatise on recent terrestrial pulmonate molluscs. Part 13. Ruthenica Supplement, Moscow. 
SMith E. A. 1898. On some land shells from Trinidad. Journal of Conchology 9: 27-29.

SOLEM A. 1989. Non-camaenid land snails of the Kimberley and Northern territory, Australia I. Systematics, affinities, and ranges. Invertebrate Taxonomy 4: 455-604. https://doi.org/10.1071/IT9880455

STANISIC J. 1981. The carnivorous land snail Gulella (Huttonella) bicolor (Hutton, 1834) in Australia (Pulmonata: Streptaxidae). Journal of the Malacological Society of Australia 5: 84-86.

https://doi.org/10.1080/00852988.1981.10673939

SuÁrEZ-TORRES A., FERnÁNDEZ-VELÁZQUEZ A. 2012 Subnicho estructural y densidad poblacional de Cerion politum maisianum y Polymita brocheri en Paso de los Azules, Maisí, Cuba. Novitates Caribaea 5: 66-72. https://doi.org/10.33800/nc.v0i5.125

TRYON G. W., PILSBRY H. A. 1889. Manual of Conchology; structural and systematic. Second Series: Pulmonata, 5. Helicidae: Vol. III. Philadelphia.

VANATTA E. G. 1920. New land shells. Proceedings of the Academy of Natural Sciences of Philadelphia 72: 203206.

VAN BRUgGen A. C. 1975. Streptaxidae (Mollusca, Gastropoda: Pulmonata) from Aldabra Island, west- ern Indian Ocean. Bulletin of the British Museum of Natural History 28: 157-175.

Vendetti J. E., LeE C., LAFollette P. 2018. Five new records of introduced terrestrial gastropods in southern California discovered by citizen science. American Malacological Bulletin 36: 232-247. https://doi.org/10.4003/006.036.0204

Vitousek P., D’ANTONio C., LOOPE L., RejMÁNeK M., WESTBROOKS R. 1997. Introduced species: a significant component of human-caused global change. New Zealand Journal of Ecology 21: 1-16.

WAgner A. J. 1907. Die Familie der Helicinidae. Neue Folge. In: MARTINI F. H. W., CHEMNITZ J. H. (eds). Systematisches Conchylien-Cabinet 1 (18) [(2)]: 1-72, pls. 1-12.

WiECZOREK J., GUO Q., HiJMANS R. 2004. The point-radius method for georeferencing locality descriptions and calculating associated uncertainty. International Journal of Geographical Information Science 18: 745-767. https://doi.org/10.1080/13658810412331280211

Received: January 30th, 2021 Revised: March 12th, 2021 Accepted: April 10th, 2021 Published on-line: May 11th, 2021 